\title{
Review
}

\section{Sartre antihumaniste: Antisujectivisme, marxisme critique, postcolonialisme}

\author{
Francesco Caddeo \\ L’Harmattan, Paris, 2020, 196pp., ISBN: 978-2343204727
}

Contemporary Political Theory (2022) 21, S150-S153. https://doi.org/10.1057/s41296021-00505-w; published online 24 June 2021

At the height of the public feud between Sartre and Foucault in the mid-1960s, Foucault dubbed Sartre's Critique of Dialectical Reason (1960) 'the magnificent and pathetic effort of a man of the nineteenth century to think the twentieth century' (Foucault, 2001, pp. 569-570). In the eyes of Foucault's generation of French philosophers (with the exception, of course, of Deleuze), Sartre's datedness lay above all in his alleged humanism. In Sartre antihumaniste: Antisujectivisme, marxisme critique, postcolonialisme (An Anti-Humanist Sartre: Anti-Subjectivism, Critical Marxism, Postcolonialism), Francesco Caddeo sets the record straight. Sartre antihumaniste provides ample evidence that Sartre, in the main, was a critic of humanism. He also argues that the Sartrean approach to subjectivity offers a way out of the antinomies of structuralism's obliteration of subjectivity, on the one hand, and, on the other, Cartesianism's substantialization and intellectualization of the same. Caddeo defends these claims with a synoptic vision of Sartre's corpus and its global reception, careful exposition of the Critique, and a nuanced comparison between Sartre and the following generation in French philosophy.

One of the great riddles of Sartre interpretation is how to make sense of his path from phenomenological existentialism in the 1940s to his later existentialist Marxism and political engagement. On this matter, there are, as Caddeo notes, basically two positions: discontinuity and continuity (pp. 115-116). Caddeo inclines in the latter direction, while offering a fresh approach to the matter. First, he contends that there is a 'transcription' or 'migration of meaning' (migration $d u$ sens) of concepts from one period to the next, but conceptual relations and linkages are not always preserved in these changes. For example, the concept of the practico-inert is the successor to Sartre's concept of facticity, but the association between facticity and the Sartrean in-itself/for-itself distinction of the 1940s is not carried through in the shift (p. 116). Second, Caddeo rejects the attempt by some, such as Alain Renaut, to isolate a good Sartre (of the early period) from a bad, supposedly pro-totalitarian Sartre of the 1950s and later. Third, Caddeo argues for the essayistic and open-ended character of Sartre's writings; in his words, Sartre's

(C) 2021 The Author(s), under exclusive licence to Springer Nature Limited. 1470-8914 Contemporary Political Theory Vol. 21, S4, S150-S153

www.palgrave.com/journals 
path is one of 'a thousand turns and diffractions' (mille tournants et diffractions) (p. 13).

In the first chapter, Caddeo surveys the Sartre of the 1930s, placing special emphasis on the thesis of the impersonality of consciousness in Transcendence of the Ego (1936). Caddeo treats the notion of impersonal consciousness as a harbinger of the theme of the death of the subject in the 1960s (p. 33). He also comments on Roquentin's rejection of humanism in the novel Nausea (1938). As Derrida points out in 'The Ends of Man,' the Sartre of the 1930s, unlike the Sartre of the subsequent decade, takes his distance from humanism, which is associated in Nausea with the ridiculed character of the Autodidact (p. 55; cf. Derrida, 1982, p. 115 n; and Sartre, 1959, p. 160). Chapter 2 then looks at Sartre's brief dalliance with humanism in the postwar period, especially in Existentialism is a Humanism. Caddeo reads Sartre as self-consciously adopting the buzzwords of the moment, when humanism-talk became hegemonic in both Catholic and Communist circles, in order to transgress and subvert sedimented meanings (pp. 57-63). It might, however, be worthwhile to spend more time considering Sartre's reliance on Henry Corbin's problematic translation of Heidegger's Dasein as 'réalité humaine' (cf. Derrida, 1982, pp. 115-116). Sartre's talk of 'man' or the 'human' in this period must also be ascribed at least in part to his anthropological reading of Heidegger's Being and Time.

The final three chapters of Sartre antihumaniste discuss Sartre's relationship with Marxism and his critique of colonialism and racism. They form the heart of the book. Caddeo engages in a close reading of both volumes of the Critique of Dialectical Reason and surrounding texts. It is not possible to do more than hint at the richness of these chapters here. The third chapter examines Sartre's attempt to marry Marxism and existentialism. Caddeo argues for a certain convergence between Althusser and Sartre in their shared rejection of the Lukács-style reification paradigm. In that paradigm, praxis is humankind's essential nature, which we lose under capitalist conditions of alienation and must then regain (pp. 71-75). In Sartre, however, praxis is not the essence of humankind, but rather the nexus of non-personal practices through which subjectivities are constituted: 'for Sartre, subjectivity arises from a multiplicity of practices and not from an 'atomistically' conceived essential being. This emergence of subjectivities is both contingent and ineliminable [non supprimable]...' (p. 93). Caddeo rounds out this picture with a detailed discussion of the dynamics of serialization and group formation in the Critique. He stresses how the concepts of 'exteriorization' and 'interiorization' come, in Sartre's later work, to replace the notions of subject and object, a move that recalls the young Sartre's rejection of a primal personal subjectivity (p. 111).

The fourth chapter further examines Sartre's notion of praxis and its cousin concept, scarcity (rarete). Praxis, Caddeo argues, is an impersonal force that forms meanings and subjects while transforming matter and prior meanings: 'Praxis,

(C) 2021 The Author(s), under exclusive licence to Springer Nature Limited. 1470-8914 Contemporary S151 Political Theory Vol. 21, S4, S150-S153 
consequently, is not to be understood as action deployed by a presumed "mastersubject" of the world, but rather as a vortex [tourbillon] of practices that are not founded in subjectivity, a vortex that, in its effects, creates the human [l'homme] as a signifying figure' (pp. 120-121). Although Caddeo himself does not draw this connection, the image of a vortex of non-subjective but subject-forming practices has a certain resonance with the images of an agencement (Deleuze) or dispositif (Foucault) of practices. As for scarcity, it is an 'ontological and existential condition' of the world, and praxis arises in response to it (p. 122). Drawing on the work of André Gorz, Caddeo shows that the Sartrean account of scarcity harbors a proto-ecological sensibility that seeks to overcome the grandiosity of humanist selfassertion. Sartre's theory of scarcity, it is argued, is the ground, both of his later forms of anti-humanism and of his critique of the messianic role assigned to the working class in Marxism, which fails to acknowledge that scarcity is more than just a conditional byproduct of the capitalist social order (pp. 131-137).

After a short discussion of Sartre's treatment of violence, Sartre antihumaniste turns, in its final chapter, to his engagement with the questions of racism, colonialism, and regionalism. Once again, Caddeo provides a series of close readings. He emphasizes the anti-essentialist critique of abstract humanism in AntiSemite and Jew while frankly admitting the limits of Sartre's brusque dismissal of the possibility of a positive Jewish identity (pp. 154-157). Sartre paves the way for a better understanding of the relationship between racism, culture, and everyday experience, but he fails in this text to think through difference adequately (p. 160). Caddeo also comments on the infamous preface to Fanon's Wretched of the Earth. He concludes the chapter with a discussion of Sartre's writings on Breton, Basque, and Québécois regionalism and on the 'new racism' targeting migrant workers in France in the 1970s (pp. 165-175).

Sartre antihumaniste overwhelmingly succeeds in demolishing the caricature of Sartre as a nineteenth century humanist. At the same time, however, by choosing to frame the book around the theme of anti-humanism, Caddeo invites the question of what exactly one is against in being against humanism. Part of the appeal of the words 'humanism' and 'human' has been - and still is - their conciliatory vagueness. There is a difference, for example, between the colonialist humanism of the French mission civilisatrice and the project of a philosophical anthropology. The relationship between the concepts 'human,' 'subject,' and 'personality' could also be illuminated. On a similar note, it would help to clarify the nature of the 'anti' in Sartre's anti-humanism. A passage that Caddeo quotes from Nausea brings home this point. Roquentin says, 'I will not be fool enough to call myself "antihumanist." I am not a humanist, that's all there is to it' (Sartre, 1969, p. 169; quoted at p. 55). Is Sartre against humanism; is he just not a humanist; or is he in favor of something like a transcendence of bourgeois European humanism toward a new, genuinely concrete and universal humanism (cf. pp. 175-176)? How does Sartre's 
stance compare, say, to Aimé Césaire's call for a 'true humanism—a humanism made to the measure of the world' (Césaire, 2001, p. 73)?

Speaking of Césaire, one curious absence from Sartre antihumaniste is 'Black Orpheus' (1948), where Sartre engages with négritude. Readers will also be struck by the negligible place Being and Nothingness occupies in this book. Although this excision - which is part of Caddeo's deliberate attempt to de-emphasize the Hegelian elements in Sartre - will certainly be controversial among Sartre scholars, there is also something provocative and compelling about the claim that Critique of Dialectical Reason represents a revitalization of themes in the Sartre of the 1930s. What is certain is that the circuit Caddeo traces through Sartre's writings rescues Sartre from Foucault's dismissiveness. Indeed, Sartre's existentialist dissident Marxism offers something like another path into the twenty-first century, one that shares many of the concerns of the 1960s generation but preserves a distinctive approach to identity, group formation, and subjectivity.

\section{References}

Césaire, A. (2001). Discourse on Colonialism. Translated by Joan Pinkham. New York: Monthly Review Press.

Derrida, J. (1982). Margins of Philosophy. Translated by Alan Bass. Chicago: University of Chicago Press.

Foucault, M. (2001). 'L'homme est-il mort?' In Dits et écrits, vol. I: 1954-1975. Edited by Daniel Defert, François Ewald, and Jacques Lagrange. Paris: 'Quarto' Gallimard.

Sartre, J.-P. (1969). Nausea. Translated by Lloyd Alexander. New York: New Directions.

Publisher's Note Springer Nature remains neutral with regard to jurisdictional claims in published maps and institutional affiliations.

Alex J. Feldman

University of West Georgia, Carrollton, GA 30118, USA afeldman@westga.edu 